This is a preprint. For an updated peer-reviewed version of this paper please visit the link below:

Shapouri, S., Martin, L.L. Snakes vs. Guns: a Systematic Review of Comparisons Between Phylogenetic and Ontogenetic Threats. Adaptive Human Behavior and Physiology (2021). https://doi.org/10.1007/s40750-021-00181-5

Snakes vs. Guns: A Systematic Review of Comparisons Between Phylogenetic and Ontogenetic Threats

\author{
Soheil Shapouri*, Leonard L. Martin*
}

*Department of Psychology, University of Georgia, Athens, GA, United States of America

Correspondence concerning this article should be addressed to

Soheil Shapouri, Department of Psychology, University of Georgia, Athens, GA, 30602.

Email: soheil.shapouri@uga.edu

Orcid ID: 0000-0001-9561-9751 


\begin{abstract}
Objectives: The potential differences between phylogenetic threats (e.g., snakes) and ontogenetic threats (e.g., guns) can have a wide-ranging impact on a variety of theoretical and practical issues, from etiology of specific phobias to stimulus selection in psychophysiological studies, yet this line of research has not been systematically reviewed.
\end{abstract}

Methods: We summarize and synthesize findings from fear conditioning, illusory correlation, attention bias, and neuroimaging studies that have compared these two types of threats to human survival.

Results: While a few brain imaging studies reveal preliminary evidence for different brain networks involved in the processing of phylogenetic and ontogenetic threats, attention bias studies tentatively show faster reaction time for modern threats, illusory correlation bias is evident for both types of threats, and fear conditioning studies are far from conclusive.

Conclusions: The results of behavioral experiments, especially attention bias research, pose a challenge to established theories like biological preparedness and fear module, as they show faster reaction time to modern threats, which is the opposite of what some evolutionary theories predict. We discuss the findings in terms of other theories that might explain the same results and conclude with potential future directions.

Keywords: phylogenetic threats, ontogenetic threats, fear module, biological preparedness 


\section{Snakes vs. Guns: A Systematic Review of Comparisons Between Phylogenetic and Ontogenetic Threats}

1. Introduction When G. Stanley Hall published "A Study of Fears" in 1897, the most common fears which his large sample reported were thunderstorms and lightning, darkness, reptiles, fire, strangers, and death; ancient threats that humans have encountered repeatedly during their evolutionary history. Since that time, our species has encountered military weapons, atomic bombs explosions and radiation exposure, cyber-attacks, car accidents, synthesized drugs, and air pollution. These modern threats are unprecedented in our evolutionary history. Whether these two kinds of threats are detected and avoided in the same way, and how they might impact humans differently has not been investigated sufficiently.

Many studies that have compared phylogenetic and ontogenetic threats rely on biological preparedness (Seligman, 1971) and fear module (Öhman \& Mineka, 2001) theories as their theoretical foundation. These theories, as outlined below, make some predictions about threatening versus non-threatening stimuli, as well as ancient versus modern threats. While the former distinction between threatening (e.g., snakes and spiders) and non-threatening (e.g, flowers and mushrooms) stimuli has been the focus of some recent review papers (e.g., Åhs et al., 2018; Wiemer \& Pauli, 2016) and whether it is supported by empirical evidence or not is debated (Del Giudice, 2020), the latter has not been systematically reviewed.

In this manuscript, we first review the work that resulted in the proposition of biological preparedness and evolved fear module. Then wereview comparisons between evolutionary and modern threats, highlight inconsistencies in the literature and discuss whether empirical studies adequately support the preparedness and fear module propositions. We conclude with other 
theories that might be considered as the basis for comparisons and some potential future directions.

\section{When Threats Were Not Different; Behaviorism and Equipotentiality With}

Pavlovian conditioning being the primary method in the study of fear learning (Stjepanović \& LaBar, 2018), behaviorism has probably contributed to the study of fears and phobias more than any other school of thought. Since its advent, behaviorism was premised on the principle of equipotentiality; the idea that mechanisms of learning apply equally to any type of stimulus and response (Domjan, 1997). However, it did not take long for this idea to be challenged even among behaviorists. After his failure in conditioning fear of wooden blocks and cloth curtains, Bregman (1934, p. 168) concluded "conditioning per se is not a cover-all explanation of emotional modifications in infancy". In another attempt, Garcia and Koelling (1966) paired audiovisual and gustatory stimuli with electric shocks, toxins, and x-rays and found that rats showed avoidance reaction toward audiovisual stimuli only when these stimuli were paired with electric shocks but not when they were paired with toxins or x-ray. Conversely, when audiovisual and gustatory stimuli were paired with toxin or x-ray, the avoidance reactions were only transferred to the gustatory stimulus, not the audiovisual stimulus.

Despite the challenges to the equipotentiality premise, behaviorists remained more interested in general learning processes than the nature of the phobic stimuli which might explain their failure in explaining the etiology of phobias. Behaviorists' account of phobias has been challenged widely in the literature and it seems conditioning falls short in explaining a variety of observations regarding fear learning. As summarized by McNally (2016), many people do not recall any traumatic experience which had resulted in their intense fear of a stimulus; in cases 
where they remember their first fearful experience with a stimulus, it is not clear why they experienced fear in the first place when they first encountered the to-be-phobic-stimulus; And “in cases, when plausible UCs [traumatic experiences] do occur, such as a dog bites or falls from high places, these events occur just as frequently in the histories of those who do not develop intense fears of dogs and heights, respectively, as in those who do." (McNally, 2016, p. 587)

Epidemiological findings, reports of the prevalence of mental disorders, were another aspect of phobia that some critics used to attack behaviorism. While animals are not the most important threat to our survival in the modern world, animal phobia is the most prevalent subtype of specific phobias worldwide (Wardenaar et al., 2017). This is a puzzling observation that evolutionary theories might answer more plausibly as this observation questions equipotentiality perspective and suggests that additional processes need to be considered for a more complete understanding of fear.

Although some researchers (e.g., Hall, 1897; Valentine, 1930; Hebb, 1946) had mentioned the role of phylogenetic mechanisms in fears and phobias, Isaac Marks (Marks, 1969, 1970) was probably the first one who highlighted the importance of these mechanisms in phobic disorders. When he observed the prepotency of certain stimuli as triggers of phobias, he concluded that "it is reasonable to expect that phylogenetic mechanisms are at least partly responsible for this prepotency of certain stimuli to produce fear in man, just as they do in other species" (Marks, 1969, p. 385). But he never provided a unifying theoretical framework to explain how these mechanisms might work. That theoretical foundation was developed later; first by Martin Seligman and later it was improved by Arne Öhman. As biological preparedness (Seligman, 1971) and evolved fear module (Öhman \& Mineka, 2001) are the groundwork for 
comparisons of phylogenetic and ontogenetic threats, we will discuss them in more details in the following sections.

3. On Rarity of Pajama Phobia: Biological Preparedness Seligman (1970) noticed the inadequacies of classical conditioning in the etiology of phobias and proposed preparedness theory which combines learning models and evolutionary theory. He distinguished between fears and phobias and argued that phobias, unlike conditioned fears, are easily acquired, resistant to extinction, irrational, and selective and concluded they are highly prepared to be learned. Above all, he highlighted the "nonarbitrariness" of phobic stimuli that was already observed by Marks; the fact that phobic stimuli are limited to objects like specific animals, open spaces, and the dark, and people rarely, if ever, have "pajama phobia" because phobic stimuli are restricted to events that were related to the survival of our species during its evolutionary history.

Despite its intuitive appeal, preparedness theory has not received much empirical support. A review by McNally (1987) found weak support of different hypotheses generated by preparedness theory. For example, one of the most important predictions of preparedness theory is that in conditioning experiments, stimuli of evolutionary significance, like pictures of snakes and spiders would show greater resistance to extinction than neutral stimuli. A systematic review (Åhs et al., 2018) of 32 fear conditioning experiments did not support this hypothesis.

In short, preparedness theory has not received strong empirical support, but it had the potential to generate falsifiable hypotheses and paved the way for a more advanced evolutionary theory of fears and phobia.

\section{Scary Serpents in the Grass; An Evolved Fear Module Advancement in} neuroimaging like identifying the role of the amygdala in emotional learning (LeDoux, 1992) on the one hand, and formulations of theories that explain how our evolutionary past shapes our 
current status (Tooby \& Cosmides, 1990) on the other hand laid the groundwork for a more sophisticated evolutionary theory of fears and phobia. Pulling together findings from cognitive neuroscience, fear conditioning experiments, and comparative psychology, Öhman and Mineka (2001) proposed an evolved module of fear and fear learning.

Humans have adaptations that reflect their evolutionary past more than their present conditions. These adaptations are successful strategies that helped them survive recurrent structures and interactions of their environment of evolutionary adaptedness (Tooby \& Cosmides, 1990). One of those recurrent problems in our evolutionary history was the detection and reaction to predation (mostly animals and aggressive conspecifics but also other dangers like height and wide-open spaces). For example, snakes have been always a danger to our survival and hence an object of fear for humans and other mammals (Öhman \& Mineka, 2003). Repetitive conditioning of cues of those dangers and deadly consequences, through the long course of evolution, has led natural selection to select for a central motive system, fear, and a related behavioral, mental, and neural system, fear module, that is specifically designed to solve the recurrent problems of threatening situations (Öhman \& Mineka, 2001).

Fear module, as described by Öhman and Mineka is a domain-specific behavioral, mental, and neural system that preferentially reacts to dangers that were life-threatening situations in our distant past and is responsible for fear eliciting and fear learning. The fear module has four characteristics. First, it is selective which means it is preferentially activated in response to fear-relevant stimuli that were important in an evolutionary perspective. Second, the activation of this system is automatic, due to the benefits of a rapid defense system. Third, it is encapsulated and impenetrable by other modules and cognitive control (i.e., logical reasoning 
cannot change it). And finally, it has a corresponding neural circuit with the centrality of the amygdala (Öhman \& Mineka, 2001).

5. Comparisons of Evolutionary and Modern Threats Both preparedness theory and fear module theory distinguish evolutionary from modern threats.

Seligman proposed that the relative preparedness of organisms vary in different situations (Seligman, 1970) and while humans are highly prepared to learn the fear of phobic stimuli that are related to the survival of our species, they are unprepared to learn an association between, for example, "electric outlet" or "hammer" and fear (Seligman, 1971).

A similar distinction has been made in the fear module theory. "A common requirement of evolutionarily shaped behavioral systems is their relative selectivity with regard to the input to which they respond. Rather than being open to any stimulus, the fear module is assumed to be particularly sensitive to stimuli that have been correlated with threatening encounters in the evolutionary past. By limiting the set of effective stimuli, readymade neural mechanisms could be devised for identifying critical events after only minimal neural processing, which would serve to facilitate rapid initiation of defense maneuvers." (Öhman \& Mineka, 2001, p. 485). And although the authors were aware that the range of stimuli that can activate the fear module might be expanded via conditioning, they reject the possibility of "a general associative mechanism that is independent of the specific to-be-associative events".

The above-mentioned distinction between evolutionary and modern threats has sparked a line of research that compares human reactions to these threats to see whether they are acquired at different rates, activate different brain regions, or are detected faster than one another. Methodologies used for this investigation tentatively depict the advancement in psychological 
research with the older studies using fear conditioning and more recent studies taking advantage of cognitive methods and brain imaging techniques.

\section{Literature Review}

Following the seminal work of Öhman and Mineka (2001) and their subsequent publications which used fear conditioning, illusory correlation bias, attention bias studies, and brain imaging to support fear module theory, we searched PubMed for relevant publications in February 2021. Two criteria were used to include the publications: reporting data in an Englishlanguage peer-reviewed journal and having both phylogenetic and ontogenetic threats as their independent variables.

The search terms "phylogenetic" AND "ontogenetic" were used in combination with "fear conditioning", "illusory correlation", "expectancy bias", "covariation bias", "attention bias", "threat detection", and "emotion processing". We also searched for "fear module" AND "biological preparedness" as they are the theoretical foundations of the comparisons. This search resulted in 47 studies. After removing duplicates $(n=14)$, the full texts of the remaining studies were scanned for inclusion. Irrelevant publications $(n=9)$, animal studies $(n=2)$, book chapter $(n=1)$, and theoretical and review papers $(n=7)$ were excluded along with the studies who only compared positive stimuli $(n=1)$ or did not include modern threats $(n=1)$. The remaining 12 papers were included in this review. Twenty-five other studies were identified by scanning the full text and reference section of these papers along with major theoretical publications in the field (Öhman \& Mineka, 2001; Sanders et al., 2003) and similar review papers (Åhs et al., 2018; Wiemer \& Pauli, 2016). The results are organized in four different tables and the last column in each table shows whether a study completely supports the prediction of fear module and 
preparedness $(+1)$ regarding the advantage of ancient threats (e.g, stronger skin conductance response for snakes and spiders), it is in the completely opposite direction (-1) and shows superiority of modern threats (e.g, faster reaction time to guns and knives), or it is not conclusive (0).

Although all evolutionary fear-relevant stimuli elicit the same emotion, fear learning of social stimuli (angry faces, faces of out-group members, and stranger anxiety) and predatory animals might have different origins (Öhman, 1986), can involve different biological or psychological mechanisms (Mallan et al., 2013), and conventionally they are studies separately. So, our review will only focus on the fear of animals.

\subsubsection{Fear Conditioning and Skin Conductance Response}

Classical conditioning, where an aversive stimulus (US) is paired with and can predict the occurrence of a neutral stimulus (CS), is now a century-old method. Emotionally charged CS (e.g, snake, angry faces, etc.) has been used widely but direct comparisons between phylogenetic and ontogenetic CSs are rare (See table 1). Those few comparisons have adopted differential protocol where a CS (i.e., CS+) predicts the occurrence of a US while another CS (i.e., CS-) does not and they all have used resistance to extinction assessed by skin conductance response as the dependent measure. Despite the similarity in general design, they have small differences which in combination with the number of studies hinder a conclusive result.

While most studies have used weapons as modern CS, Hugdahl and kärkar (1981) used electrical outlets. Flykt et al. (2007) use of backward masking (brief exposure to target CS for 25 ms immediately followed by exposure to a mask for $125 \mathrm{~ms}$ ) with the aim of investigating unconscious processing of threats makes it incomparable with others. Yet Luck et al. (2020) study is different in its within-subject design and use of instructed extinction (informing 
participants about the absence of US before extinction trials) to see whether the criterion of encapsulation from cognition is met. The variety of US is also evident as some studies have used electric shocks, others have utilized an aversive tone, yet some have applied both.

If despite experimental variation, any conclusion is warranted here, it would not support preparedness or fear module predictions regarding stronger resistance to extinction in evolutionary threats. While three experiments did not find any difference between evolutionary and modern threats, the other three found results in different directions. So, four out of six studies did not find any evidence in favor of fear module prediction regarding stronger resistance to extinction in evolutionary threats.

\section{Table 1}

Fear Conditioning and Skin Conductance Studies

\begin{tabular}{|c|c|c|c|c|c|c|c|}
\hline Study & Paradigm & Design & CS+ & US & $\mathbf{N}^{*}$ & $\begin{array}{c}\text { Resistance to } \\
\text { extinction } \\
\text { measured by SCR }\end{array}$ & \\
\hline $\begin{array}{c}\text { Hugdahl \& Kärker, } \\
1981\end{array}$ & $\begin{array}{l}\text { differential } \\
\text { conditioning }\end{array}$ & $\begin{array}{l}\text { between- } \\
\text { subject }\end{array}$ & $\begin{array}{l}\text { snakes, spiders / } \\
\text { electric outlet / } \\
\text { geometrical } \\
\text { figures }\end{array}$ & shock & 45 & $\begin{array}{c}\text { stronger for } \\
\text { evolutionary } \\
\text { threats }\end{array}$ & 1 \\
\hline $\begin{array}{c}\text { Cook, Hodes, \& Lang, } \\
1986 \\
\text { Exp } 1\end{array}$ & $\begin{array}{l}\text { differential } \\
\text { conditioning }\end{array}$ & $\begin{array}{l}\text { between- } \\
\text { subject }\end{array}$ & $\begin{array}{c}\text { snakes, spiders / } \\
\text { guns / houses, } \\
\text { household objects }\end{array}$ & noise & 42 & $\begin{array}{l}\text { stronger for } \\
\text { evolutionary } \\
\text { threats }\end{array}$ & 1 \\
\hline $\begin{array}{c}\text { Flykt, Esteves, \& } \\
\text { Öhamn, } 2007 \\
\text { Exp } 1\end{array}$ & $\begin{array}{c}\text { backward masking } \\
+ \text { differential } \\
\text { conditioning }\end{array}$ & $\begin{array}{l}\text { between- } \\
\text { subject }\end{array}$ & $\begin{array}{l}\text { snakes / guns } \\
\text { (directed toward } \\
\text { participants) }\end{array}$ & $\begin{array}{c}\text { shock for } \\
\text { evolutionary } \\
\text { threats / } \\
\text { noise for } \\
\text { modern } \\
\text { threats }\end{array}$ & 64 & no difference & 0 \\
\hline
\end{tabular}




\begin{tabular}{|c|c|c|c|c|c|c|c|}
\hline $\begin{array}{c}\text { Flykt, Esteves, \& } \\
\text { Öhamn, } 2007 \\
\text { Exp } 2\end{array}$ & $\begin{array}{c}\text { backward masking } \\
\text { + differential } \\
\text { conditioning }\end{array}$ & $\begin{array}{l}\text { between- } \\
\text { subject }\end{array}$ & $\begin{array}{c}\text { snakes / guns } \\
\text { (averted away } \\
\text { from participants) }\end{array}$ & $\begin{array}{c}\text { shock for } \\
\text { evolutionary } \\
\text { threats / } \\
\text { noise for } \\
\text { modern } \\
\text { threats }\end{array}$ & 32 & no difference & 0 \\
\hline $\begin{array}{c}\text { Luck, Patterson, \& } \\
\text { Lipp, } 2020\end{array}$ & $\begin{array}{c}\text { differential } \\
\text { conditioning + } \\
\text { Instructed } \\
\text { extinction }\end{array}$ & within-subject & $\begin{array}{c}\text { snakes, spiders / } \\
\text { guns }\end{array}$ & $\begin{array}{c}\text { shock and } \\
\text { noise }\end{array}$ & 80 & no difference & 0 \\
\hline $\begin{array}{c}\text { Hugdahl \& Johnson, } \\
1989\end{array}$ & $\begin{array}{l}\text { differential } \\
\text { conditioning }\end{array}$ & $\begin{array}{l}\text { between- } \\
\text { subject }\end{array}$ & snakes / guns & $\begin{array}{c}\text { shock and } \\
\text { noise }\end{array}$ & 80 & $\begin{array}{l}\text { stronger for } \\
\text { modern threats }\end{array}$ & -1 \\
\hline
\end{tabular}

*The first two studies had three groups (evolutionary threats, modern threats, and neutral) while the other studies had only two groups of evolutionary and modern threats. For the sake of consistency, we have reported all stimuli and the total number of participants for the first two studies.

\subsubsection{Discussion of Fear Conditioning Studies}

Our review of conditioning experiments is consistent with a systematic review by Åhs and his colleagues (2018) which found that from 32 fear conditioning experiments comparing fear-relevant and fear-irrelevant stimuli (mostly snakes and spiders versus flowers and mushrooms), only $31 \%$ had reported stronger resistance to extinction in fearful pictures while $69 \%$ did not support preparedness idea. On the other hand, Del Giudice (2020) used a metaanalytic approach to reanalyze the same set of studies reviewed by Åhs and his colleagues and actually found weak support for biological preparedness. But the major finding of Del Giudice was that most fear conditioning studies were underpowered and hence unable to detect the effect of interest if it exists. So, lack of sufficient power might explain why most studies did not find any difference between modern and evolutionary threats.

In sum, when the number of studies along with small sample sizes of most studies are added to their methodological dissimilarities, fear conditioning studies do not allow a firm 
conclusion. Almost a century after pioneering works by Watson and Raynor (1920) the first compendium for fear conditioning was published in 2017 (Lonsdorf et al., 2017). So, the methodological disparities of the studies conducted over the span of four decades should not be surprising. Some researchers (e.g, LeDoux, 2014) have highlighted the importance of research on possible different defense circuits underlying innate and learned fears, and searching "fear conditioning" in PubMed shows the number of fear conditioning studies has been rising steadily in the past two decades. Our hope is this manuscript, once again, underscores the importance of comparing evolutionary and modern threats by using standardized conditioning protocols.

\subsubsection{Illusory Correlation}

The role of cognitive biases in anxiety disorders has been long agreed upon (Mineka \& Sutton, 1992; Ouimet, Gawronski \& Dozois, 2009). The cognitive bias in people with an intense fear of some stimuli might lead to overestimation of the relationship between threatening events and aversive outcomes which is called illusory correlation. Tomarken, Mineka, and Cook (1989) proposed a method, called illusory correlation, that aims to capture these biases. In this method, typically 72 slides of fear-relevant and fear-irrelevant stimuli are followed by three possible outcomes: electrical shock, noise, or nothing. Although each stimulus is equally likely to be followed by each outcome, an overestimation of the relationship between fear-relevant stimuli and aversive outcome, especially in clinical samples of phobic patients, is expected. If participants are asked to give their estimates before the experiment, the bias is called expectancy bias (or a priori). Estimates that are given after the experiment, are called covariation bias (or a posteriori). 
While the presence of a fear-relevant cognitive bias suggests an illusory correlation, biological preparedness and fear module predict a stronger bias for evolutionary fear-relevant stimuli compared to modern fear-relevant stimuli. The latter possibility has been investigated in several studies of the illusory correlation paradigm (See table 2).

Before we review the results of those studies it is important to note that the primary purpose of most of these studies was not to evaluate preparedness theory or fear module, but to show the cognitive biases of people suffering from specific phobia or subclinical anxiety. Consequently, some have reported the results separately for people with high and low fear and not for the entire sample. Clinical studies have reported the findings for before- and aftertreatment groups. More importantly, instead of statistical differences between modern and evolutionary threats, most of them have reported the mere presence or absence of illusory correlation for these stimuli. To know that whether the illusory correlation bias is stronger for evolutionary threats or modern threats, correlation coefficients for these threats should be compared and that comparison needs the transformation of correlation coefficients (r) to $\mathrm{z}$ scores. But none of these studies have reported z scores. Despite this problem, and the discrepancies in reporting style mentioned above, getting a general picture is still possible.

\section{Table 2}

Illusory Correlation Studies

$\mathrm{EV}=$ evolutionary, $\mathrm{MO}=$ modern, $\mathrm{CB}=$ covariation bias, $\mathrm{EB}=$ expectancy bias

\begin{tabular}{|l|l|l|l|l|l|}
\hline Study & Stimuli & Outcome & N & Results* \\
\hline
\end{tabular}




\begin{tabular}{|c|c|c|c|c|c|}
\hline $\begin{array}{c}\text { de Jong, } \\
\text { Merchelbach, Arntz } \\
\text { \& Nijman, } 1992\end{array}$ & $\begin{array}{l}\text { spider /knives, } \\
\text { guns /flowers }\end{array}$ & $\begin{array}{c}\text { shock, neutral noise, } \\
\text { nothing }\end{array}$ & $\begin{array}{c}\text { clinical } \\
\text { (20 treated } 18 \\
\text { untreated) }\end{array}$ & $\begin{array}{c}\mathrm{CB} \text { for } \mathrm{EV} \text { in untreated } \\
\text { no } \mathrm{CB} \text { for } \mathrm{MO} \text { or } \mathrm{EV} \text { in treated }\end{array}$ & $\begin{array}{l}1 \\
0\end{array}$ \\
\hline $\begin{array}{c}\text { de Jong, } \\
\text { Merchelbach \& } \\
\text { Arntz, } 1995\end{array}$ & $\begin{array}{l}\text { spider /knives, } \\
\text { guns /flowers }\end{array}$ & shock, siren, noise & $\begin{array}{c}\text { clinical } \\
\text { (19 treated } 19 \\
\text { untreated) }\end{array}$ & $\begin{array}{l}\text { EB for both, stronger CB for EV, } \\
\text { marginal stronger online EB for } \\
\text { evo, and no online EB in untreated } \\
\text { no EB in treated } \\
\text { no CB in treated }\end{array}$ & $\begin{array}{l}1 \\
1 \\
0 \\
0\end{array}$ \\
\hline $\begin{array}{c}\text { Mühlberger, } \\
\text { Wiedemann, } \\
\text { Herrmann, \& Pauli, } \\
2006\end{array}$ & $\begin{array}{l}\text { spiders /airplane } \\
\text { crashes } \\
\text { /mushrooms }\end{array}$ & startle tone, nothing & $\begin{array}{c}\text { clinical } \\
\text { (17 spider-phobic, } 17 \\
\text { flight-phobic) }\end{array}$ & $\begin{array}{l}\text { EB for both groups } \\
\text { CB for spider-phobic }\end{array}$ & $\begin{array}{l}0 \\
1\end{array}$ \\
\hline $\begin{array}{l}\text { Tomarken, Sutton \& } \\
\text { Mineka, 1995, exp } 1\end{array}$ & $\begin{array}{c}\text { snakes /damages } \\
\text { electrical outlets } \\
\text { /flowers, } \\
\text { mushrooms }\end{array}$ & shock, tone, nothing & 64 & $\begin{array}{l}\text { CB for EV in high fear } \\
\text { no CB in low fear }\end{array}$ & 1 \\
\hline $\begin{array}{c}\text { Amin \& Lovibond, } \\
1997\end{array}$ & $\begin{array}{l}\text { snakes, spiders } \\
\text { /guns, knives } \\
\text { /flowers, } \\
\text { mushrooms }\end{array}$ & shock, tone, nothing & 40 & $\begin{array}{c}\text { EB for both } \\
\text { CB for EV in high fear }\end{array}$ & 1 \\
\hline de Jong, 1993 & $\begin{array}{c}\text { spiders /weapons } \\
\text { /flowers }\end{array}$ & shock, siren, nothing & 64 & $\begin{array}{l}\text { EB for both (marginally stronger } \\
\text { EB for EV) in high fear } \\
\text { EB for both (marginally stronger } \\
\text { EB for EV) in low fear }\end{array}$ & $\begin{array}{l}1 \\
1\end{array}$ \\
\hline $\begin{array}{c}\text { Honeybourne, } \\
\text { Matchette \& Davey, } \\
1993\end{array}$ & $\begin{array}{l}\text { snakes, spiders / } \\
\text { guns, electrical } \\
\text { outlets /flowers, } \\
\text { landscape }\end{array}$ & $\begin{array}{c}\text { noise + vibration, } \\
\text { nothing } \\
\text { (instructed not } \\
\text { presented) }\end{array}$ & 35 & EB for both & 0 \\
\hline $\begin{array}{c}\text { Kennedy, Rapee \& } \\
\text { Mazurski, } 1997\end{array}$ & $\begin{array}{c}\text { snakes, spiders / } \\
\text { damaged electrical } \\
\text { outlets and }\end{array}$ & shock, tone, nothing & 42 & EB for both in high fear & $\begin{array}{l}0 \\
-1 \\
0\end{array}$ \\
\hline
\end{tabular}




\begin{tabular}{|c|c|c|c|c|c|}
\hline & $\begin{array}{c}\text { appliances } \\
\text { /flowers }\end{array}$ & & & $\begin{array}{l}\text { EB for both in low fear (stronger } \\
\qquad \text { EB for MO) } \\
\text { CB for both in high fear } \\
\text { no CB in low fear (not different } \\
\text { between EV and MO) }\end{array}$ & 0 \\
\hline $\begin{array}{l}\text { Lovibond, Hanna, } \\
\text { Siddle \& Bond, } \\
\text { 1994, exp } 1\end{array}$ & $\begin{array}{l}\text { spider, snake / gun } \\
\text { / flowers, } \\
\text { mushroom }\end{array}$ & $\begin{array}{c}\text { electric shock } \\
\text { (instructed not } \\
\text { presented), nothing }\end{array}$ & 29 & $\begin{array}{l}\text { EB for both (not statistically } \\
\text { different) }\end{array}$ & 0 \\
\hline $\begin{array}{l}\text { Lovibond, Hanna, } \\
\text { Siddle \& Bond, } \\
\text { 1994, exp } 2\end{array}$ & $\begin{array}{l}\text { snake, spider / gun } \\
\text { /mushrooms, } \\
\text { flower, mountains, } \\
\text { trees }\end{array}$ & $\begin{array}{l}\text { shock (instructed but } \\
\text { notpresented), } \\
\text { nothing }\end{array}$ & 40 & $\begin{array}{c}\text { EB for both } \\
\text { (not statistically different) }\end{array}$ & 0 \\
\hline $\begin{array}{l}\text { Lovibond, Hanna, } \\
\text { Siddle \& Bond, } \\
\text { 1994, exp } 3\end{array}$ & $\begin{array}{l}\text { snake, spider /gun } \\
\text { / plant, mushroom } \\
\text { flower desk } \\
\text { organizer tape } \\
\text { dispenser abstract } \\
\text { colorful circle } \\
\text { triangle square etc. }\end{array}$ & $\begin{array}{l}\text { shock (instructed but } \\
\text { notpresented). } \\
\text { nothing }\end{array}$ & 32 & no EB & 0 \\
\hline $\begin{array}{c}\text { McNally \& } \\
\text { Heatherton, 1993, } \\
\text { exp } 1 \& 2\end{array}$ & $\begin{array}{c}\text { snakes /flowers, } \\
\text { mushrooms } \\
\text { damaged electrical } \\
\text { outlets /flowers, } \\
\text { mushroom }\end{array}$ & shock, tone, nothing & $\begin{array}{l}40 \\
44\end{array}$ & EB for both & 0 \\
\hline $\begin{array}{c}\text { Muris, de Jong, } \\
\text { Meesters, Waterreus } \\
\text { \& Lubeck, 2005, exp } \\
1\end{array}$ & $\begin{array}{l}\text { spider /weapon } \\
\text { /Pokémon }\end{array}$ & $\begin{array}{c}\text { winning candy, } \\
\text { losing candy, nothing }\end{array}$ & $\begin{array}{c}\text { children } \\
147\end{array}$ & no $\mathrm{CB}$ & 0 \\
\hline $\begin{array}{l}\text { Muris, de Jong, } \\
\text { Meesters, Waterreus } \\
\text { \& Lubeck, 2005, exp } \\
2\end{array}$ & $\begin{array}{l}\text { spider /weapon / } \\
\text { Pokémon }\end{array}$ & $\begin{array}{l}\text { winning candy, } \\
\text { losing candy, nothing }\end{array}$ & $\begin{array}{c}\text { children } \\
240\end{array}$ & no $\mathrm{CB}$ & 0 \\
\hline
\end{tabular}




\begin{tabular}{|c|c|c|c|c|c|}
\hline $\begin{array}{c}\text { Muris, Huijding, } \\
\text { Mayer, Breejen \& } \\
\text { Makkelie, 2007, exp } \\
1\end{array}$ & spider /gun /flower & shock, nothing & $\begin{array}{l}\text { children and } \\
\text { adolescents } \\
73 \text { (9-11 years) } \\
77 \text { (12-16 years) }\end{array}$ & $\begin{array}{c}\text { EB for both } \\
\text { (not statistically different) }\end{array}$ & $\begin{array}{l}0 \\
0\end{array}$ \\
\hline $\begin{array}{l}\text { Murris, Huijding, } \\
\text { Mayer, Breejen \& } \\
\text { Makkelie, 2007, exp } \\
2\end{array}$ & $\begin{array}{l}\text { spider /gun / } \\
\text { flower }\end{array}$ & $\begin{array}{l}\text { win candy, lose } \\
\text { candy, nothing }\end{array}$ & $\begin{array}{c}\text { children } \\
220\end{array}$ & CB for both & 0 \\
\hline $\begin{array}{c}\text { Davey \& Dixon, } \\
\text { 1996, exp } 2\end{array}$ & $\begin{array}{l}\text { snakes. spiders } \\
\text { /gun electrical } \\
\text { outlet /flower, } \\
\text { landscape }\end{array}$ & $\begin{array}{l}\text { noise + vibration, } \\
\text { flashlight, nothing }\end{array}$ & 40 & $\begin{array}{c}\text { EB for both } \\
\text { No CB }\end{array}$ & -1 \\
\hline
\end{tabular}

* Whenever direct comparisons by statistical analysis have been made, the results are reported in parentheses.

Regarding expectancy bias, with only two exceptions (de Jong et al., 1995; Lovibond et al., 1994, exp 3), participants expected both kinds of threats to be followed by aversive outcomes more often than neutral stimuli. So, there is enough evidence of illusory correlation between threats and aversive outcomes. Although the majority of studies have not reported statistical comparisons between evolutionary and modern threatening stimuli, of those who have done so, four of them found stronger correlation for ancient threats and only one for modern threats. In short, the general pattern is in favor of fear module and preparedness theories although it might be weak.

Considering covariation bias in healthy adults, three experiments find covariation bias for evolutionary threats in high fear individuals (Mühlberger et al., 2006; Tomarken et al., 1995, experiment 1; Amin \& Lovibond, 1997), and one experiment failed to find such a difference (Kennedy et al., 1997). Yet one study did not observe any covariation bias for either category (Davey \& Dixon, 1996, experiment 2). Studies with children and adolescents either did not find 
any covariation bias or it was not different between the two kinds of threats. Although both clinical studies found covariation bias in untreated phobic patients, it seems it is not a phenomenon that can be easily observed in healthy children, youth, and adults with low fear of ancient threats.

\subsubsection{Illusory Correlation Bias Discussion}

Our review of illusory correlation bias studies shows that while expectancy bias is evident for both evolutionary and modern threats, people might show a weak preexisting bias toward ancient fear-relevant objects. In other words, people expect threatening stimuli to be followed by aversive outcomes, but this expectation might be slightly different between ontogenetic and phylogenetic threats. The picture is a little vague when it comes to covariation bias. Some studies did not find any covariation bias, some found the bias but it was not different for evolutionary and modern threats. And in some cases, particularly studies which had clinical samples, covariation bias for evolutionary threats was present only in untreated patients. In a nutshell, covariation bias for evolutionary dangers can be a characteristic of clinical samples and not the general population.

In a review of fear-relevant illusory correlation studies, Wiemer and Pauli (2016) found a clear overestimation of fear-relevant stimuli and aversive outcome in animal phobia. A closer look at their findings shows that from 14 studies of expectancy bias in animal phobia 12 found a bias toward fear-relevant objects. For covariation bias, however, the bias was more obvious in clinical samples than in subclinical studies. In studies on phobic patients, 6 studies found covariation bias and 2 did not. But in subclinical samples, the proportion was 8 to 5 . Obviously, this bias is more pronounced in phobic patients. So, the general pattern of our findings is 
consistent with Wiemer and Pauli's study. The lack of a more notable difference between

evolutionary and modern threats in terms of covariation bias should underline one important aspect of those studies. Most of these studies have recruited people with high fear of evolutionary threats (i.e., snakes and spiders) except McNally and Heatherton (1993) who had participants with high fear of a modern object (i.e., damaged electrical outlets). So, the expectancy and covariation bias for evolutionary fear-relevant objects observed in some studies that include clinical or subclinical subjects with animal phobia does not necessarily support the fear module theory in the general population.

\subsubsection{Attention Bias Studies}

Based on the benefits of fast and automatic detection of ancient threats proposed by fear module theory, threat-related attention bias has been another domain where evolutionary and modern threats have been compared to explore the possibility that one has an advantage in capturing our attention over the other. Öhman, Flykt, and Esteves (2001) used a visual search task to show that fear-relevant stimuli of evolutionary significance are detected faster possibly by a parallel search mechanism which is independent of the number of distractors or the size of the display. In this task, participants are asked to detect the presence (or absence) of a target among three or eight distractors as fast as possible. A faster reaction time can be interpreted as attention bias toward a particular stimulus and a number of studies have used this method to investigate a possible advantage of evolutionary threats over modern ones in capturing attention (see table 3 ). A few other studies have used dot-probe, inattentional blindness, or cuing paradigms to answer the same question.

\section{Table 3}


Attention Bias and Reaction Time

\begin{tabular}{|c|c|c|c|c|c|}
\hline Study & Paradigm & Stimuli & $\mathbf{N}$ & Results & \\
\hline Blanchette, 2006, exp 2 & visual Search Task & $\begin{array}{l}\text { block 1: snakes, spiders / gun } \\
\text { knife / flowers, mushrooms } \\
\text { /clicks toasters } \\
\text { block } 2 \& 3 \text { : cartoon and } \\
\text { photographs of toys of same } \\
\text { stimuli as block } 1\end{array}$ & 25 & $\begin{array}{l}\text { block 1: faster } \\
\text { reaction time to } \\
\text { evolutionary threats } \\
\text { block } 2 \& 3 \text { : No } \\
\text { difference }\end{array}$ & $\begin{array}{l}1 \\
0\end{array}$ \\
\hline Yang et al. 2012 & eye-tracking & $\begin{array}{l}\text { snakes, spiders, scorpions, rats, } \\
\text { etc. / } \\
\text { ax, gun, syringe, etc. }\end{array}$ & 25 & $\begin{array}{l}\text { not different in the } \\
\text { human context } \\
\text { but different in non- } \\
\text { human context } \\
\text { (longer gaze } \\
\text { duration and more } \\
\text { gaze fixations for } \\
\text { negative animals } \\
\text { than negative } \\
\text { objects) }\end{array}$ & 1 \\
\hline $\begin{array}{c}\text { Vida \& Behrmann, (2017) } \\
\qquad \text { Exp } 1 \& 2\end{array}$ & $\begin{array}{l}\text { monocular/dichoptic } \\
\text { behavioral paradigm }\end{array}$ & $\begin{array}{l}\text { snakes, spiders / } \\
\text { guns } \\
\text { / neutral pics }\end{array}$ & $\begin{array}{l}\exp 1: 35 \\
\exp 2: 36\end{array}$ & $\begin{array}{l}\text { monocular } \\
\text { advantage for } \\
\text { evolutionary } \\
\text { threats, but not for } \\
\text { modern threats }\end{array}$ & 1 \\
\hline Erlich et al., 2013 & $\begin{array}{c}\text { inter-beat intervals / EMG / } \\
\text { visual orientation }\end{array}$ & $\begin{array}{c}\text { auditory stimuli } \\
\text { thunderstorm, angry voice, } \\
\text { baby crying, etc. / siren } \\
\text { wailing, bomb exploding, etc. / } \\
\text { baby laughing, Beethoven } \\
\text { music, etc. }\end{array}$ & $\begin{array}{c}\text { infants } \\
61\end{array}$ & $\begin{array}{l}\text { larger heart rate } \\
\text { deceleration, startle } \\
\text { eye-blinks, and } \\
\text { more visual } \\
\text { orienting in } \\
\text { response to } \\
\text { evolutionary threats }\end{array}$ & 1 \\
\hline Brosch \& Sharma, 2005 & visual search task & $\begin{array}{l}\text { snakes, spiders / guns, syringes } \\
\text { / flowers, mushrooms / cups, } \\
\text { mobile phones }\end{array}$ & 63 & no difference & 0 \\
\hline
\end{tabular}




\begin{tabular}{|c|c|c|c|c|c|}
\hline $\begin{array}{c}\text { Fox, Griggs \& } \\
\text { Mouchlianitis, 2007, exp } 2\end{array}$ & visual search task & $\begin{array}{c}\text { snakes / guns / mushrooms, } \\
\text { toasters }\end{array}$ & 20 & no difference & 0 \\
\hline $\begin{array}{c}\text { Fox, Griggs \& } \\
\text { Mouchlianitis, 2007, exp } 1\end{array}$ & visual search task & $\begin{array}{c}\text { snakes / guns / mushrooms, } \\
\text { flowers }\end{array}$ & 30 & no difference & 0 \\
\hline $\begin{array}{c}\text { Carlson, Fee, \& Reinke } \\
2009\end{array}$ & $\begin{array}{l}\text { dot-probe (backward } \\
\text { masking) }\end{array}$ & $\begin{array}{l}\text { snakes, spiders, bugs / knives, } \\
\text { syringes, guns / birds, bunny, } \\
\text { trees, shells / basket, fan, chair, } \\
\text { and bus }\end{array}$ & 30 & no difference & 0 \\
\hline Gao \& Jia, 2017 & $\begin{array}{c}\text { inattentional blindness } \\
\text { (detection rate of unexpected } \\
\text { illustrations) }\end{array}$ & $\begin{array}{l}\text { snakes, spiders / guns, knives / } \\
\text { umbrella, clock, tree, flower }\end{array}$ & 192 & $\begin{array}{l}\text { no difference (both } \\
\text { detected more } \\
\text { frequently) }\end{array}$ & 0 \\
\hline $\begin{array}{c}\text { Zsido, Csatho, Matuz, } \\
\text { Stecina, Arato, Inhof \& } \\
\text { Darnai, 2019, exp } 1\end{array}$ & $\begin{array}{l}\text { modified visual search task } \\
\text { (evolutionary or modern } \\
\text { backgrounds) }\end{array}$ & $\begin{array}{l}\text { snakes / gun / cat, pen (on } \\
\text { evolutionary and modern } \\
\text { background) }\end{array}$ & 34 & no difference & 0 \\
\hline $\begin{array}{c}\text { Zsido, Csatho, Matuz, } \\
\text { Stecina, Arato, Inhof \& } \\
\text { Darnai, 2019, exp } 2\end{array}$ & $\begin{array}{l}\text { modified visual search task } \\
\text { (evolutionary and modern } \\
\text { backgrounds) }\end{array}$ & $\begin{array}{l}\text { snake, spider, scorpion / cat, } \\
\text { bird, turtle / gun, knife, syringe } \\
\text { / pen, flashlight, toaster }\end{array}$ & 33 & no difference & 0 \\
\hline $\begin{array}{l}\text { Young, S. G., Brown, C. M., } \\
\text { \& Ambady, N. (2012) }\end{array}$ & spatial-cueing task & $\begin{array}{l}\text { snakes, spiders / guns, knives } \\
\text { (context primes: outdoor } \\
\text { wooded scene and hiking trails } \\
\text { vs. city streets and urban } \\
\text { scene) }\end{array}$ & 62 & $\begin{array}{l}\text { greater attentional } \\
\text { deployment for } \\
\text { evolutionary } \\
\text { threats, following } \\
\text { nature prime } \\
\text { greater attentional } \\
\text { deployment for } \\
\text { modern threats, } \\
\text { following urban } \\
\text { primes }\end{array}$ & 0 \\
\hline $\begin{array}{l}\text { Zsido, A. N., Deak, A., } \\
\text { Losonci, A., Stecina, D., } \\
\text { Arato, A., \& Bernath, L. } \\
\text { (2018) }\end{array}$ & visual search task & spider / ladybird / syringe / pen & $\begin{array}{c}\text { children } \\
68\end{array}$ & no difference & 0 \\
\hline
\end{tabular}




\begin{tabular}{|c|c|c|c|c|c|}
\hline $\begin{array}{c}\text { Brown, El-Deredy \& } \\
\text { Blanchette, } 2010\end{array}$ & dot-probe task (RT) & $\begin{array}{l}\text { snakes, spiders / ropes and } \\
\text { trees / knives and syringes / } \\
\text { spoons and pens }\end{array}$ & 32 & $\begin{array}{l}\text { modern cues lead to } \\
\text { faster reaction time } \\
\text { (both evolutionary } \\
\text { and modern threats } \\
\text { led to increased P1 } \\
\text { amplitude, although } \\
\text { the effect was } \\
\text { stronger for modern } \\
\text { threats) }\end{array}$ & -1 \\
\hline $\begin{array}{l}\text { Subra, Muller, Fourgassie, } \\
\text { Chauvin \& Alexopoulos, } \\
2018\end{array}$ & dot-probe task & $\begin{array}{l}\text { spiders, snakes, scorpions / } \\
\text { guns, knives,grenades }\end{array}$ & 60 & $\begin{array}{l}\text { faster reaction time } \\
\text { to modern threats }\end{array}$ & -1 \\
\hline Blanchette, 2006, exp 1 & visual search task & $\begin{array}{l}\text { snakes spiders / gun, knife / } \\
\text { flowers, mushrooms /clicks, } \\
\text { toasters }\end{array}$ & 35 & $\begin{array}{l}\text { faster reaction time } \\
\text { to modern threats }\end{array}$ & -1 \\
\hline $\begin{array}{c}\text { Zsido, Deak \& Bernath, } \\
2019\end{array}$ & visual search task & $\begin{array}{c}\text { snakes / guns / flowers, mobile } \\
\text { phones }\end{array}$ & 53 & $\begin{array}{l}\text { faster reaction time } \\
\text { to modern threats }\end{array}$ & -1 \\
\hline Blanchette, 2006, exp 3 & visual search task & $\begin{array}{l}\text { block 1: similar to exp 1\& } 2 \\
\text { block } 2 \text { : lions, rats / rabbit, } \\
\text { goldfish / syringes, hand } \\
\text { grenade / pens, balls }\end{array}$ & 36 & $\begin{array}{l}\text { block 1: faster } \\
\text { reaction time to } \\
\text { modern threats } \\
\text { block 2: no } \\
\text { difference }\end{array}$ & $\begin{array}{l}-1 \\
0\end{array}$ \\
\hline
\end{tabular}

As table 3 shows, while most studies have failed to find any difference between evolutionary and modern threats, some have found an advantage for modern threats to capture attention. Among eighteen experiments reported here, only four of them have reported faster reaction time to evolutionary threats and five experiments found faster reaction time for modern threats. This is the opposite of what preparedness and fear module theories predict. It is important to note that unlike fear conditioning and illusory correlation bias studies, the majority of attention 
bias studies controlled for low-level visual features (e.g., luminance, contrast, image complexity, etc.) and emotional aspects (valance and arousal) of stimuli. So, the general pattern found here cannot be attributed to those characteristics. While a precise conclusion about the superiority of modern threats needs a meta-analytic approach, rejecting fear module prediction regarding stronger attention bias toward evolutionary relative to modern threats is warranted.

Attention bias studies have used visual stimuli and the only exception is Erlich et al. (2013) which used auditory stimuli to look at physiological responses of 9-month-old infants to evolutionary and modern fear-relevant and fear-irrelevant stimuli. Their research is also unique regarding recruiting infants who could not have that much experience with any of the threats. In their study of 61 infants (mean age 8.76 and 24 female), they played evolutionary threatening sounds (e.g., thunderstorm, angry voice, baby crying), modern threatening sounds (e.g., siren wailing, bomb exploding), and pleasant sounds (e.g., baby laughing, Beethoven music). Larger heart rate deceleration and larger startle eye-blinks were observed when infants were listening to evolutionary threatening sounds in comparison to modern threatening and pleasant sounds. Visual orienting behavior (turning toward caregiver or the source of sound) was marginally different between evolutionary and modern threats with more frequent orienting toward the former than the latter.

\subsubsection{Attention Bias Discussion}

The majority of attention-bias studies did not find any difference between evolutionary and modern threats and of nine studies which found a difference five of them show an advantage for modern threats in capturing our attention. For a long time, the idea of a subcortical pathway 
for the fast processing of emotionally charged stimuli has been the standard hypothesis in the field. Based on his animal studies on rodents, Ledoux (1998) proposed that this "low road" that goes through superior colliculus and pulvinar of thalamus to the amygdala can bypass the cortex for rapid and dirty processing of emotional stimuli. Later, neuroimaging studies in humans (Morris et al. 2002) showed increased connectivity between right amygdala, colliculus and pulvinar in response to fear-conditioned faces. Öhman, Flykt, and Esteves (2001) study which used visual search task and showed that snakes and spiders capture our attention faster than mushrooms and flowers popularized the notion that a faster subcortical route can facilitate the detection of evolutionary threats while a cortical pathway responsible for the detection of modern threats is slower. Pessoa and Adolphs (2010) criticized this notion, argued that the assumption of a subcortical pathway in which visual processing is faster than cortex is faulty, and proposed a multi-wave model that puts more emphasis on cortex than the amygdala. Our results further support their view. Even if the neural pathways underlying detection and reaction to modern and evolutionary threats are different (see section 5.4 and 6.4) attention bias studies show the subcortical pathway is by no means faster than the cortex.

The Erlich et al. (2013) research on infants using auditory stimuli has two novel aspects. First, it is highly unlikely that their findings reflect their participants' experiences with threats as their age range was $8.14-9.19$ months. The possibility that human species are born with an innate fear of evolutionary threats and only later in the course of development learn to fear modern objects remains to be explored in future studies. Second, the use of auditory stimuli in this study is another aspect that makes it unique but also incomparable with other studies. Indeed, the idea of a low road for processing emotional stimuli comes in part from fear conditioning studies on rodents that typically use auditory signals as conditioned stimuli. Pessoa 
and Adophs (2010) highlighted this point and added that the auditory system of rodents and the visual system of primates and humans are not analogous, the auditory system has higher temporal precision, and unlike vision, it is omnidirectional. Is it possible that a fear module exists but instead of the visual system it is lied down in the human auditory system? The fact that some species of snakes hiss a warning before they bite (Coelho et al., 2019) along with evolutionary accounts of sound localization in mammals (Heffner, 1997; Heffner \& Heffner, 1992) suggest this is a road worth exploring.

If priming (Young et al. 2012) or background (Zsido et al., 2019) facilitates faster reaction time to some threatening or neutral evolutionary stimuli, then fear module theory is not the most parsimonious explanation of these findings and there are other theories that better explain them. Sanders et al. (2003) proposed that the amygdala does not only react to negative threatening events but a wide range of rewarding positive objects including happy faces, amusement-inducing films, and positive pictures as well. So, the amygdala is a module with all four characteristics that fear module theory describes but it is better to be considered as an evolved system for relevance detection whose job is to evaluate any biologically or socially relevant event. The relevance detection hypothesis which is a more parsimonious version of the fear module can better explain the findings of attention bias studies.

Attention bias studies also reveal one more important challenge to the evolutionary account provided by fear module theory. Theaverage reaction time to modern and evolutionary threats reported in most studies is around $1000 \mathrm{~ms}$ with a standard deviation of about $100 \mathrm{~ms}$. Coelho and his colleagues (2019) found that most snakebites happen when humans are 3 to 60 cm away from the snake and snakes' strikes usually occur in less than $100 \mathrm{~ms}$. These authors interpreted their results as a serious challenge to the ecological validity of fear module studies. 
We think this logic can be applied to all mammalian species that might encounter snakes. After measuring the speed of strikes by snakes and comparing it to startle responses of mammals, human's eye blink, and jumping acceleration of black-tailed jackrabbits, Penning and his colleagues (2016) reached the conclusion that snakes "make the strikes faster than the sensory and motor responses of mammalian prey and predators." We cannot refute the survival benefits of fast detection of snakes when they are in long distance from the prey but when participants who are focused on detecting snakes among just three or eight other distractors are by far slower than most species of snakes, fast detection of them in a natural setting, like a dense forest, is at best a dubious assumption.

\subsubsection{Neuroimaging Studies}

A few studies have explored the possibility of differences between evolutionary and modern threats by looking at physiological responses to these two sets of stimuli. There are scarce but combined together they might give us a clearer picture of possible underlying mechanisms of threat responses.

\begin{tabular}{|c|c|c|c|c|c|}
\hline Study & Paradigm & Stimuli & $\mathrm{N}$ & Results & \\
\hline $\begin{array}{l}\text { Dhum et } \\
\text { al., } 2017\end{array}$ & fMRI & $\begin{array}{c}\text { predatory } \\
\text { animals / guns, } \\
\text { knives, cars, } \\
\text { ships, airplanes } \\
\text { accidents }\end{array}$ & 41 & $\begin{array}{l}\text { stronger activation in threat-processing network } \\
\text { in response to evolutionary threats }\end{array}$ & 1 \\
\hline
\end{tabular}




\begin{tabular}{|c|c|c|c|c|c|}
\hline $\begin{array}{l}\text { Fang et al., } \\
\qquad 2016\end{array}$ & fMRI & $\begin{array}{l}\text { predatory } \\
\text { animals / guns, } \\
\text { axes, etc. }\end{array}$ & 62 & $\begin{array}{l}\text { stronger activation of the amygdala and } \\
\text { subcortical regions in response to evolutionary } \\
\text { threats especially with human context }\end{array}$ & 1 \\
\hline $\begin{array}{l}\text { Zhang \& } \\
\text { Guo, } 2019\end{array}$ & ERP & $\begin{array}{l}\text { snakes, spiders, } \\
\text { etc. / guns, } \\
\text { knives, syringes }\end{array}$ & 96 & $\begin{array}{l}\text { stronger visual mismatch negativity in response } \\
\text { to evolutionary threats in occipital regions }\end{array}$ & 1 \\
\hline $\begin{array}{l}\text { Cao et al., } \\
2014\end{array}$ & fMRI & $\begin{array}{l}\text { snakes, spiders, } \\
\text { etc. / guns, } \\
\text { syringes, etc. }\end{array}$ & 67 & $\begin{array}{l}\text { higher amygdala activation in response to } \\
\text { evolutionary threats in non-human context, } \\
\text { Higher amygdala activation in response to } \\
\text { modern threats in the human context }\end{array}$ & 0 \\
\hline $\begin{array}{l}\text { Brown et } \\
\text { al., } 2010\end{array}$ & ERP & $\begin{array}{l}\text { snakes, spiders } \\
\text { /ropes, trees } \\
\text { /knives, } \\
\text { syringes } \\
\text { /spoons, pens }\end{array}$ & 32 & $\begin{array}{l}\text { both evolutionary and modern threats led to } \\
\text { increased P1 amplitude, although the effect was } \\
\text { stronger for modern threats }\end{array}$ & -1 \\
\hline
\end{tabular}

An fMRI study (Dhum et al., 2017) with 41 healthy subjects (21 female) measured brain activity in response to a wide range of evolutionary and modern threats and found higher activity bilaterally in the posterior cingulate and the parahippocampal gyrus for modern threats and stronger activity for evolutionary threats in left inferior frontal gyrus and thalamus, right middle frontal gyrus and parietal regions as well as bilaterally in parietal regions, fusiform gyrus and bilateral amygdala. Another interesting finding of this study was that while modern threats 
received higher negative ratings of valance in post-experiment rating, evolutionary threats provoke stronger activation of the threat-processing network.

Two other fMRI studies have investigated the role of the amygdala in processing evolutionary and modern threats when visual stimuli contain parts of the human body, although they found opposite patterns. Cao and his colleagues (2014) found that the human amygdala responds more strongly to negative animals than negative objects. But if parts of the human body were included in the photos, higher amygdala activation was observed for threatening objects than threatening animals. On the other hand, Fang et al. (2016) used masked stimuli and found the opposite. Masked threatening animals provoked stronger activation in subcortical regions and the amygdala particularly when there were presented with human-related information.

Lack of temporal precision of fMRI necessitates the use of other brain imaging techniques, mainly EEG, which has the potential of detecting rapid information processes related to threat perception. Zhang and Guo (2019) used ERPs to investigate visual mismatch negativity evoked by threatening modern and evolutionary stimuli. In a study of 96 healthy subjects (64 female), they asked participants to focus on auditory stimuli and ignore visual threatening and non-threatening stimuli. The analysis of visual mismatch negativity (subtraction of ERPs evoked by neutral stimuli from ERPs generated by threatening stimuli) following visual display of stimuli, showed larger visual mismatch negativity in response to phylogenetic threats compared to ontogenetic ones obtained from parieto-occipital and occipital regions. The results have been interpreted as a prepared, pre-attentive, and automatic response to evolutionary threats. As part of their attention bias study, Brown and his colleagues (2010; mentioned in section 5.3.1) measured P1 amplitude and found an increase in P1 amplitude in response to threatening pictures but this effect was stronger for modern threats. 


\subsubsection{Neuroimaging Studies Discussion}

Although the general pattern of physiological studies supports the idea of different neural mechanisms responsible for the reaction to evolutionary and modern threats, extreme caution should be exercised in interpreting their results as they are not replicated yet and they are sometimes contradicted by studies that are partially similar.

Shu and Quingke (2019) study shows that larger visual mismatch negativity is elicited by evolutionary threats than modern objects. On the contrary, Brown et al.'s (2010) attention bias study which used a dot-probe task along with EEG has reported a larger P1 amplitude in response to phylogenetic threats than ontogenetic fear-relevant stimuli. As the range of eventrelated brain potential components better overlaps with the speed of snakes, EEG studies in future might provide some clues for human threat detection. Still, the slower rate of translation of ERP components to human body reactions should be considered as a challenge to the ecological validity of those studies.

The only fMRI study (Dhum et al., 2017) with the aim of direct comparisons between evolutionary and modern threats has a serious methodological issue that might undermine the reliability of its findings (See note 1). But there is another study that we did not discuss in our review of neuroimaging studies as it was not published in a high-quality peer-review journal. de Rojas \& Kensinger (2010) re-analyzed data from two other fMRI studies and found that orbitofrontal cortex reacts more strongly to modern threats than evolutionary threatening stimuli. Two other brain imaging studies (Cao et al. 2014; Fang et al.,2016) further supports the notion of different brain mechanisms for these threats but the patterns of higher and lower amygdala activation in response to threats depending on the presence or absence of human context depicts 
the amygdala as a more flexible module for appraisal of relevance (Guex et al., 2020) than a rigid module of fear. Once again, looking at the amygdala as the relevance detector (Sanders, et al., 2003) is a better explanation of the findings than fear module theory.

6. General Discussion Here we reviewed four decades of research inspired by biological preparedness and fear module theory. Despite the popularity of those theories, empirical studies do not support some of their predictions. Considering the parsimony as a criterion for good theories, a few studies that to some extent support the fear module, are better explained by evolved relevance detection theory. However, it is highly unlikely that the issues discussed in this manuscript are resolved any time soon. More than a century after the first systematic study of fears by G Stanley Hall, disagreement around the study of fear is more than before, not less. A discussion among seven prominent researchers in the field held by Nature Neuroscience (Mobbs, et al., 2019) showed that there is not any agreement on the definition of fear and the best ways to study it, although it seems the value of the evolutionary approach was an issue that fear experts agreed upon. When we cross disciplines, this disagreement is even more pronounced. LoBue and Adolph (2019) reviewed three classic fears in infants, snakes and spiders, height, and strangers and concluded that, in the absence of any negative emotion and avoidance, the differential reaction of infants and children to those dangers in comparisons to neutral objects cannot be easily attributed to fear. That is exactly why we think the comparisons of evolutionary and modern threats should be continued. Without controlling the evolutionary age of stimuli under investigation any results could be disputed more easily.

Except for attention bias, direct comparisons of phylogenetic and ontogenetic threats are rare but definitely can be a fruitful line of research. Fear conditioning studies in humans, in 
particular, can be helpful as their findings are comparable to most animal research but researchers need to control the emotional aspects of stimuli (valence and arousal) as they highly affect physiological reactions to threatening and non-threatening stimuli (Bradley \& Lang, 2007). Future studies can also benefit from using auditory stimuli. Heavy reliance on vision modality has made the findings comparable across human studies but to some extent incomparable with fear conditioning studies in rodents. It should be reminded that the proposition of a subcortical route for quick evaluation of emotional stimuli (LeDoux, 1998) was partly based on studies on mice and subcortical projections from auditory thalamus to lateral amygdaloid nucleus (LeDoux et al., 1990). So, until other modalities are investigated fully, the results of this review remain pertinent only to vision.

The consistency of different labs in picking the same visual stimuli in this lineage is another aspect that needs attention. Using snakes and spiders as evolutionary threats, guns as modern threats, and flowers and mushrooms for neutral condition enables researchers to compare and contrast the outcomes of studies. However, this approach might rise some questions regarding ecological validity. Snakebites are responsible for 94000 - 125000 deaths annually (WHO, 2018) and snakes have been considered as the prototype of evolutionary threatening stimuli (e.g, Öhman, 1986; Öhman \& Mineka, 2003; Isbell, 2006). But an investigation of natural disasters between 1981 - 2002 (Neumayer \& Plümper, 2007) shows in that period, windstorms with 1121 incidents were the most common form of natural disaster, estimated mortality due to droughts exceed 550,000, and more than 1,700,000,000 people have been affected by around 900 floods across the globe. In the same vein, car accidents are among the top ten causes of death (WHO, 2018). So, the definition of "prototypes" of evolutionary and modern threats is not completely driven by data. 
Although traditionally evolutionary psychology has assumed predation was the major driver of the evolution of the fear system, there is evidence that climate-related events also play an important role in our evolution (Behrensmeyer, 2006). For example, humans were able to settle down and start the agricultural revolution only after the amelioration of climate variability (Bowles \& Choi, 2013). On the other hand, some studies (Baum et al., 1983, Brun, 1992, Siegrist \& Sütterlin, 2014) suggest that decision making, risk perception, and affective reactions to natural and technological disasters are different. Assuming that the dichotomy of ancient versus modern threats is applicable to natural versus technological disasters, the latter could provide an opportunity for researchers to expand this line of research.

Considering the importance of going beyond western, educated, industrialized, rich, and democratic (WEIRD) samples for evolutionary psychology (Apicella et al., 2020), it is important to note that except for a few studies in Hungary and China, most studies we reviewed are conducted on WEIRD populations. Studies in other cultures can benefit the field but crosscultural comparisons have even better potential. To illustrate the point, we can compare the United States and India, two countries with high mortality due to gun violence and snakebites respectively. In 2014, guns claimed more than 33000 deaths in the United States and around 4000 in India (Alpers \& Picard, 2020). Snakebites mortalities estimate in India is around 58000 annually with an estimation of about one million bites in 2015 (Suraweera et al., 2020). The United States has a mortality rate close to zero but between $7000-8000$ of estimated venomous bites (NIOSH, 2020). Situations like this provide opportunities for cross-cultural naturalistic studies that can shed light on human adaptability and provide experimental controls for "familiarity" and "threatening value" that only a few studies have controlled by subjective ratings. Besides familiarity, the lethality of threats is another aspect that researchers have not 
controlled but to be sure that possible differences between phylogenetic and ontogenetic threats are related to evolutionary age and not their relative severity, lethality should be taken into consideration.

7. Conclusion The comparisons between evolutionary and modern threats can shed light on different important aspects of evolutionary mechanisms, from massive modularity and adaptive lag to universalism of human nature. While neuroimaging studies provide support for differential neural processing of phylogenetic and ontogenetic threats, further research is needed to understand how these differences are translated to behavioral outcomes. One possible solution would be to generate and test hypotheses by relying on theories like the evolved module of relevance detection which are better backed by neuroscience research. Since current psychological measures have failed to show the possible differences between evolutionary and modern threats, future behavioral and cognitive research can benefit from studying infants, using auditory stimuli, and combining neuroimaging and behavioral measures. 
Notes

1. This study has a major technical issue. The authors claim that they have used a wide range of predatory animals (e.g., snakes, spiders, sharks, dogs, and bears) for evolutionary-threatening condition. The id numbers of IAPS photos used in this study and reported in its supplementary material, show they have only picked snakes. The first author did not respond to our emails about this issue. 


\section{Conflict of Interest}

The authors declare that they have no conflict of interest. 


\section{References}

Åhs, F., Rosén, J., Kastrati, G., Fredrikson, M., Agren, T., \& Lundström, J. N. (2018). Biological preparedness and resistance to extinction of skin conductance responses conditioned to fear relevant animal pictures: A systematic review. Neuroscience \& Biobehavioral Reviews, 95, 430437. https://doi.org/10.1016/j.neubiorev.2018.10.017

Alpers, P. \& Picard, M. (2020). United States - Gun Facts, Figures and the Law. Retrieved Oct 10, 2020, from https://www.gunpolicy.org/firearms/region/united-states

Alpers, P. \& Picard, M. (2020). India - Gun Facts, Figures and the Law. Retrieved Oct 10, 2020, from https://www.gunpolicy.org/firearms/region/india

Amin, J. M., \& Lovibond, P. F. (1997). Dissociations between covariation bias and expectancy bias for fear-relevant stimuli. Cognition \& Emotion, 11(3), 273-289. https://doi.org/10.1080/026999397379926

Apicella, C., Norenzayan, A., Henrich, J. (2020). Beyond WEIRD: A review of the last decade and a look ahead to the global laboratory of the future. Evolution and Human Behavior, 41(5), 319 329. https://doi.org/10.1016/j.evolhumbehav.2020.07.015

Baum, A., Fleming, R., \& Davidson, L. M. (1983). Natural disaster and technological catastrophe. Environment and Behavior, 15(3), 333-354.

Behrensmeyer, A. K. (2006). Climate Change and Human Evolution. Science, 311(5760), 476-478.

Blanchette, I. (2006). Snakes, spiders, guns, and syringes: How specific are evolutionary constraints on the detection of threatening stimuli?. Quarterly journal of experimental psychology, 59(8), 14841504. https://doi.org/10.1080/02724980543000204 
Bowles, S., \& Choi, J. K. (2013). Coevolution of farming and private property during the early Holocene. Proceedings of the National Academy of Sciences, 110(22), 8830-8835.

Bradley, M. M., \& Lang, P. J. (2007). Emotion and motivation. In Cacioppo, J. T., Tassinary, L. G., \& Berntson, G. (Eds.), Handbook of psychophysiology (pp. 581 - 607). Cambridge university press.

Bregman, E. O. (1934). An attempt to modify the emotional attitudes of infants by the conditioned response technique. The Pedagogical Seminary and Journal of Genetic Psychology, 45(1), 169198. https://doi.org/10.1080/08856559.1934.10534254

Brosch, T., \& Sharma, D. (2005). The role of fear-relevant stimuli in visual search: a comparison of phylogenetic and ontogenetic stimuli. Emotion, 5(3), 360 - 364. https://doi.org/10.1037/15283542.5.3.360

Brown, C., El-Deredy, W., \& Blanchette, I. (2010). Attentional modulation of visual-evoked potentials by threat: investigating the effect of evolutionary relevance. Brain and cognition, 74(3), 281-287. https://doi.org/10.1016/j.bandc.2010.08.008

Brun, W. (1992). Cognitive components in risk perception: Natural versus manmade risks. Journal of Behavioral Decision Making, 5(2), 117-132.

Cao, Z., Zhao, Y., Tan, T., Chen, G., Ning, X., Zhan, L., \& Yang, J. (2014). Distinct brain activity in processing negative pictures of animals and objects - The role of human contexts. Neuroimage, 84, 901-910. https://doi.org/10.1016/j.neuroimage.2013.09.064

Carlson, J. M., Fee, A. L., \& Reinke, K. S. (2009). Backward masked snakes and guns modulate spatial attention. Evolutionary Psychology, 7(4), 147470490900700404. https://doi.org/10.1177/147470490900700404 
Coelho, C. M., Suttiwan, P., Faiz, A. M., Ferreira-Santos, F., \& Zsido, A. N. (2019). Are humans prepared to detect, fear, and avoid snakes? The mismatch between laboratory and ecological evidence. Frontiers in psychology, 10. https://doi.org/10.3389/fpsyg.2019.02094

Cook, E. W., Hodes, R. L., \& Lang, P. J. (1986). Preparedness and phobia: effects of stimulus content on human visceral conditioning. Journal of abnormal psychology, 95(3), 195 - 207. https://doi.org/10.1037/0021-843X.95.3.195

Davey, G. C., \& Dixon, A. L. (1996). The expectancy bias model of selective associations: the relationship of judgments of CS dangerousness, CS-UCS similarity and prior fear to a priori and a posteriori covariation assessments. Behaviour Research and Therapy, 34(3), 235-252. https://doi.org/10.1016/0005-7967(96)88487-7

de Jong, P. J., Merckelbach, H., Arntz, A., \& Nijmam, H. (1992). Covariation detection in treated and untreated spider phobics. Journal of Abnormal Psychology, 101(4), 724 - 727. https://doi.org/10.1037/0021-843X.101.4.724

de Jong, P. J., Merckelbach, H., \& Arntz, A. (1995). Covariation bias in phobic women: The relationship between a priori expectancy, on-line expectancy, autonomic responding, and a posteriori contingency judgment. Journal of Abnormal Psychology, 104(1), 55 - 62. https://doi.org/10.1037/0021-843X.104.1.55

de Jong, P. J. (1993). Covariation bias in phobia: Mere resistance to preexperimental expectancies?. Behavior Therapy, 24(3), 447-454. https://doi.org/10.1016/S0005$\underline{7894(05) 80217-5}$ 
Del Giudice, M. (2020). Åhs et al.’s (2018) Systematic review on biological preparedness and resistance to extinction: A commentary and reanalysis. Neuroscience and Biobehavioral Reviews, 120, 1315. https://doi.org/10.1016/j.neubiorev.2020.11.009

Dhum, M., Herwig, U., Opialla, S., Siegrist, M., \& Brühl, A. B. (2017). Evolutionary and modern image content differentially influence the processing of emotional pictures. Frontiers in human neuroscience, 11. https://doi.org/10.3389/fnhum.2017.00415

Domjan, M. (1997). Behavior systems and the demise of equipotentiality: Historical antecedents and evidence from sexual conditioning. In M. E. Bouton \& M. S. Fanselow (Eds.), Learning, motivation, and cognition: The functional behaviorism of Robert C. Bolles (p. 31-51). American Psychological Association. https://doi.org/10.1037/10223-002

Erlich, N., Lipp, O. V., \& Slaughter, V. (2013). Of hissing snakes and angry voices: human infants are differentially responsive to evolutionary fear-relevant sounds. Developmental science, 16(6), 894-904. https://doi.org/10.1111/desc.12091

Fang, Z., Li, H., Chen, G., \& Yang, J. (2016). Unconscious processing of negative animals and objects: role of the amygdala revealed by fMRI. Frontiers in human neuroscience, 10. https://doi.org/10.3389/fnhum.2016.00146

Flykt, A., Esteves, F., \& Öhman, A. (2007). Skin conductance responses to masked conditioned stimuli: Phylogenetic/ontogenetic factors versus direction of threat?. Biological psychology, 74(3), 328336. https://doi.org/10.1016/j.biopsycho.2006.08.004

Fox, E., Griggs, L., \& Mouchlianitis, E. (2007). The detection of fear-relevant stimuli: Are guns noticed as quickly as snakes?. Emotion, 7(4), 691 - 696. https://doi.org/10.1037/1528-3542.7.4.691 
Gao, H., \& Jia, Z. (2017). Detection of threats under inattentional blindness and perceptual load. Current Psychology, 36(4), 733-739. https://doi.org/10.1007/s12144-016-9460-0

Garcia, J., \& Koelling, R. A. (1966). Relation of cue to consequence in avoidance learning. Psychonomic science, 4(1), 123-124. https://doi.org/10.3758/BF03342209

Guex, R., Méndez-Bértolo, C., Moratti, S., Strange, B. A., Spinelli, L., Murray, R. J., Sander, D., Seeck, M., Vuilleumier, P., \& Domínguez-Borràs, J. (2020). Temporal dynamics of amygdala response to emotion-and action-relevance. Scientific Reports, 10(1), 1-16. https://doi.org/10.1038/s41598020-67862-1

Hall, G. S. (1897). A study of fears. The American Journal of Psychology, 8(2), 147-249. https://doi.org/10.2307/1410940

Hebb, D. O. (1946). On the nature of fear. Psychological Review, 53(5), 259-276. https://doi.org/10.1037/h0061690

Heffner, R. S. (1997). Comparative study of sound localization and its anatomical correlates in mammals. Acta Oto-Laryngologica, 117(sup532), 46-53. https://doi.org/10.3109/00016489709126144

Heffner, R. S., \& Heffner, H. E. (1992). Evolution of sound localization in mammals. In The evolutionary biology of hearing (pp. 691-715). Springer. https://doi.org/10.1007/978-1-46122784-7_43

Honeybourne, C., Matchett, G., \& Davey, G. C. (1993). Expectancy models of laboratory preparedness effects: A UCS-expectancy bias in phylogenetic and ontogenetic fear-relevant stimuli. Behavior Therapy, 24(2), 253-264. https://doi.org/10.1016/S0005-7894(05)80267-9 
Hugdahl, K., \& Kärker, A. C. (1981). Biological vs experiential factors in phobic conditioning. Behaviour research and therapy, 19(2), 109-115. https://doi.org/10.1016/00057967(81)90034-6

Hugdahl, K., \& Johnsen, B. H. (1989). Preparedness and electrodermal fear-conditioning: Ontogenetic vs phylogenetic explanations. Behaviour Research and Therapy, 27(3), 269-278. https://doi.org/10.1016/0005-7967(89)90046-6

Isbell, L. A. (2006). Snakes as agents of evolutionary change in primate brains. Journal of human evolution, 51(1), 1-35. https://doi.org/10.1016/j.jhevol.2005.12.012

Kennedy, S. J., Rapee, R. M., \& Mazurski, E. J. (1997). Covariation bias for phylogenetic versus ontogenetic fear-relevant stimuli. Behaviour Research and Therapy, 35(5), 415-422. https://doi.org/10.1016/S0005-7967(96)00128-3

LeDoux, J. E. (1992). Emotion and the amygdala. In J. P. Aggleton (Ed.), The amygdala: Neurobiological aspects of emotion, memory, and mental dysfunction (p. 339-351). Wiley-Liss.

LeDoux, J. (2014). Rethinking the Emotional Brain. In Dębiec, J., Heller, M., Brożek, B., LeDoux, J. (Eds.), The Emotional Brian Revisited (pp. 13 - 83) Copernicus Center Press. https://doi.org/10.1016/j.neuron.2012.02.004

LeDoux, J. (1998). The emotional brain: The mysterious underpinnings of emotional life. Simon and Schuster. 
LeDoux, J. E., Cicchetti, P., Xagoraris, A., \& Romanski, L. M. (1990). The lateral amygdaloid nucleus: sensory interface of the amygdala in fear conditioning. Journal of neuroscience, 10(4), 10621069. DOI: https://doi.org/10.1523/JNEUROSCI.10-04-01062.1990

LoBue, V., \& Adolph, K. E. (2019). Fear in infancy: Lessons from snakes, spiders, heights, and strangers. Developmental psychology, 55(9), 1889-1907. https://doi.org/10.1037/dev0000675

Lonsdorf, T. B., Menz, M. M., Andreatta, M., Fullana, M. A., Golkar, A., Haaker, J., ... \& Drexler, S. M. (2017). Don't fear 'fear conditioning': Methodological considerations for the design and analysis of studies on human fear acquisition, extinction, and return of fear. Neuroscience \& Biobehavioral Reviews, 77, 247-285. https://doi.org/10.1016/j.neubiorev.2017.02.026

Lovibond, P. F., Hanna, S. K., Siddle, D. A., \& Bond, N. W. (1994). Electrodermal and subjective reactions to fear-relevant stimuli under threat of shock. Australian Journal of Psychology, 46(2), 73-80. https://doi.org/10.1080/00049539408259476

Luck, C. C., Patterson, R. R., \& Lipp, O. V. (2020). "Prepared” fear or socio-cultural learning? Fear conditioned to guns, snakes, and spiders is eliminated by instructed extinction in a withinparticipant differential fear conditioning paradigm. Psychophysiology, 57(4), e13516. https://doi.org/10.1111/psyp.13516

Mallan, K. M., Lipp, O. V., \& Cochrane, B. (2013). Slithering snakes, angry men and out-group members: What and whom are we evolved to fear?. Cognition \& Emotion, 27(7), 1168-1180. https://doi.org/10.1080/02699931.2013.778195

Marks, I. M. (2013). Fears and phobias. Academic Press.

Marks, I. M. (1970). The classification of phobic disorders. The British Journal of Psychiatry, 116(533), 377-386. doi:10.1192/bjp.116.533.377 
McNally, R. J. (2016). The legacy of Seligman's "phobias and preparedness" (1971). Behavior therapy, 47(5), 585-594. https://doi.org/10.1016/j.beth.2015.08.005

McNally, R. J. (1987). Preparedness and phobias: a review. Psychological bulletin, 101(2), 283-303. https://doi.org/10.1037/0033-2909.101.2.283

McNally, R. J., \& Heatherton, T. F. (1993). Are covariation biases attributable to a priori expectancy biases?. Behaviour Research and Therapy, 31(7), 653-658. https://doi.org/10.1016/00057967(93)90118-E

Mineka, S., \& Sutton, S. K. (1992). Cognitive biases and the emotional disorders. Psychological Science 3(1). https://doi.org/10.1111/j.1467-9280.1992.tb00260.x

Morris, J. S., deBonis, M., \& Dolan, R. J. (2002). Human amygdala responses to fearful eyes. Neuroimage, 17(1), 214-222. https://doi.org/10.1006/nimg.2002.1220

Mobbs, D., Adolphs, R., Fanselow, M. S., Barrett, L. F., LeDoux, J. E., Ressler, K., \& Tye, K. M. (2019). Viewpoints: Approaches to defining and investigating fear. Nature neuroscience, 22(8), 1205-1216. https://doi.org/10.1038/s41593-019-0456-6

Muris, P., De Jong, P. J., Meesters, C., \& Waterreus, B. (2005). An experimental study of spider-related covariation bias in 8-to 13-year-old children. Child psychiatry and human development, 35(3), 185-201. https://doi.org/10.1007/s10578-004-6457-y

Muris, P., Huijding, J., Mayer, B., den Breejen, E., \& Makkelie, M. (2007). Spider fear and covariation bias in children and adolescents. Behaviour Research and Therapy, 45(11), 2604-2615. https://doi.org/10.1016/j.brat.2007.06.002 
Mühlberger, A., Wiedemann, G., Herrmann, M. J., \& Pauli, P. (2006). Phylo-and ontogenetic fears and the expectation of danger: Differences between spider-and flight-phobic subjects in cognitive and physiological responses to disorder-specific stimuli. Journal of Abnormal Psychology, 115(3), 580. https://doi.org/10.1037/0021-843X.115.3.580

National Institute for Occupational Safety and Health. (2020). Venomous Snakes. Center for Disease Control and Prevention. Retrieved on Oct 10, 2010 from https://www.cdc.gov/niosh/topics/snakes/default.html

Neumayer, E., \& Plümper, T. (2007). The gendered nature of natural disasters: The impact of catastrophic events on the gender gap in life expectancy, 1981-2002. Annals of the Association of American Geographers, 97(3), 551-566. https://doi.org/10.1111/j.1467-8306.2007.00563.x

Öhman, A. (1986). Face the beast and fear the face: Animal and social fears as prototypes for evolutionary analyses of emotion. Psychophysiology, 23(2), 123-145. https://doi.org/10.1111/j.1469-8986.1986.tb00608.x

Öhman, A., \& Mineka, S. (2001). Fears, phobias, and preparedness: toward an evolved module of fear and fear learning. Psychological review, 108(3), 483. https://doi.org/10.1037/0033295X.108.3.483

Öhman, A., Flykt, A., \& Esteves, F. (2001). Emotion drives attention: detecting the snake in the grass. Journal of experimental psychology: general, 130(3), 466. https://doi.org/10.1037/00963445.130.3.466

Öhman, A., \& Mineka, S. (2003). The malicious serpent: Snakes as a prototypical stimulus for an evolved module of fear. Current directions in psychological science, 12(1), 5-9. https://doi.org/10.1111/1467-8721.01211 
Ouimet, A. J., Gawronski, B., \& Dozois, D. J. (2009). Cognitive vulnerability to anxiety: A review and an integrative model. Clinical psychology review, 29(6), 459-470. https://doi.org/10.1016/j.cpr.2009.05.004

Penning, D. A., Sawvel, B., \& Moon, B. R. (2016). Debunking the viper's strike: harmless snakes kill a common assumption. Biology letters, 12(3), 20160011. https://doi.org/10.1098/rsbl.2016.0011

Pessoa, L., \& Adolphs, R. (2010). Emotion processing and the amygdala: from a 'low road' to 'many roads' of evaluating biological significance. Nature reviews neuroscience, 11(11), 773-782. https://doi.org/10.1038/nrn2920

Sander, D., Grafman, J., \& Zalla, T. (2003). The human amygdala: an evolved system for relevance detection. Reviews in the Neurosciences, 14(4), 303-316. https://doi.org/10.1515/REVNEURO.2003.14.4.303

Schreier, A., \& Evans, G. (2003). Adrenal cortical response of young children to modern and ancient stressors. Current Anthropology, 44(2), 306-309. https://doi.org/10.1086/367974

Seligman, M. E. (1970). On the generality of the laws of learning. Psychological review, 77(5), 406-418. https://doi.org/10.1037/h0029790

Seligman, M. E. (1971). Phobias and preparedness. Behavior therapy, 2(3), 307-320. $\underline{\text { https://doi.org/10.1016/S0005-7894(71)80064-3 }}$

Siegrist, M., \& Sütterlin, B. (2014). Human and nature-caused hazards: The affect heuristic causes biased decisions. Risk Analysis, 34(8), 1482-1494.

Stjepanović, D., \& LaBar, K. S. (2018). The Cognitive Neuroscience of Fear Learning. Stevens' Handbook of Experimental Psychology and Cognitive Neuroscience, 1, 1-39. 
Subra, B., Muller, D., Fourgassie, L., Chauvin, A., \& Alexopoulos, T. (2018). Of guns and snakes: testing a modern threat superiority effect. Cognition and emotion, 32(1), 81-91. https://doi.org/10.1080/02699931.2017.1284044

Suraweera, W., Warrell, D., Whitaker, R., Menon, G., Rodrigues, R., Fu, S. H., Begum, R., Sati, P., \& Piyasena, K. (2020). Trends in snakebite deaths in India from 2000 to 2019 in a nationally representative mortality study. Elife, 9, e54076.

Tomarken, A. J., Mineka, S., \& Cook, M. (1989). Fear-relevant selective associations and covariation bias. Journal of Abnormal Psychology, 98(4), 381-394. https://doi.org/10.1037/0021843X.98.4.381

Tomarken, A. J., Sutton, S. K., \& Mineka, S. (1995). Fear-relevant illusory correlations: What types of associations promote judgmental bias?. Journal of abnormal psychology, 104(2), 312-326. https://doi.org/10.1037/0021-843X.104.2.312

Tooby, J., \& Cosmides, L. (1990). The past explains the present: Emotional adaptations and the structure of ancestral environments. Ethology and sociobiology, 11(4-5), 375-424. https://doi.org/10.1016/0162-3095(90)90017-Z

Valentine, C. W. (1930). The innate bases of fear. The Journal of Genetic Psychology, 37, 394-420. https://doi.org/10.1080/00221325.1991.9914710

Watson, J. B., \& Rayner, R. (1920). Conditioned emotional reactions. Journal of experimental psychology, 3(1), 1-14. https://doi.org/10.1037/h0069608

World Health Organization. (2018). The Top Ten Causes of Death. Retrieved Oct 10, 2010, from https://www.who.int/news-room/fact-sheets/detail/the-top-10-causes-of-death 
World Health Organization. (2018). Animal Bites. Retrieved Oct 10, 2010, from https://www.who.int/news-room/fact-sheets/detail/animal-bites

Wiemer, J., \& Pauli, P. (2016). Fear-relevant illusory correlations in different fears and anxiety disorders: A review of the literature. Journal of anxiety disorders, 42, 113-128. https://doi.org/10.1016/j.janxdis.2016.07.003

Wardenaar, K. J., Lim, C. C., Al-Hamzawi, A. O., Alonso, J., Andrade, L. H., Benjet, C., ... \& Gureje, O. (2017). The cross-national epidemiology of specific phobia in the World Mental Health Surveys. Psychological medicine, 47(10), 1744. https://doi.org/10.1017/S0033291717000174

Young, S. G., Brown, C. M., \& Ambady, N. (2012). Priming a natural or human-made environment directs attention to context-congruent threatening stimuli. Cognition \& emotion, 26(5), 927-933. https://doi.org/10.1080/02699931.2011.625399

ZHANG, S., \& GUO, Q. (2019). Superiority Effect in Detecting Phylogenetic Threats Under Unattentional Condition: A Visual Mismatch Negativity Study. Psychology Research, 9(9), 353370. doi:10.17265/2159-5542/2019.09.002

Zsido, A. N., Deak, A., \& Bernath, L. (2019). Is a snake scarier than a gun? The ontogeneticphylogenetic dispute from a new perspective: The role of arousal. Emotion, 19(4), 726. https://doi.org/10.1037/emo0000478

Zsido, A. N., Deak, A., Losonci, A., Stecina, D., Arato, A., \& Bernath, L. (2018). Investigating evolutionary constraints on the detection of threatening stimuli in preschool children. Acta psychologica, 185, 166-171. https://doi.org/10.1016/j.actpsy.2018.02.009 
Zsido, A. N., Csatho, A., Matuz, A., Stecina, D. T., Arato, A., Inhof, O., \& Darnai, G. (2019). Does threat have an advantage after all?-Proposing a novel experimental design to investigate the advantages of threat-relevant cues in visual processing. Frontiers in psychology, 10, 2217. https://doi.org/10.3389/fpsyg.2019.02217 